\title{
SELEKSI MASSA DALAM UPAYA PENINGKATAN PRODUKTIVITAS JAGUNG LOKAL VARIETAS GULUK-GULUK
}

\author{
Henny Diana Wati ${ }^{1 *}$, Ida Ekawati ${ }^{2)}$, Purwati Ratna ${ }^{3)}$ \\ 1)*, 2), 3) Dosen Fakultas Pertanian Universitas Wiraraja Madura \\ E-mail : hennydianawati97@gmail.com ${ }^{1)^{*}}$
}

\begin{abstract}
ABSTRAK
Penelitian ini bertujuan menerapkan seleksi massa dalam upaya meningkatkan produktivitas jagung lokal varietas guluk-guluk. Penelitian ini menggunakan metode kuantitatif dalam bentuk evaluasi populasi awal P0 dan populasi P1 tanaman jagung lokal varietas guluk-guluk, komponen produksi yang diamati, meliputi : 1). Berat biji per tongkol, 2). Berat tongkol tanpa biji, 3). Jumlah biji per tongkol, 4) Jumlah biji dalam satu baris per tongkol, dan 5). Panjang tongkol. Data hasil pengamatan dianalisis dengan menggunakan analisis uji t-test pada taraf 5\%. Hasil penelitian setelah satu siklus dari populasi awal (P0) hingga populasi hasil seleksi (P1) menunjukkan kemajuan yang berbeda nyata untuk semua sifat yang diamati. Pada populasi hasil seleksi (P1) terjadi peningkatan nilai rerata populasi pada semua sifat yang di amati Hal ini berarti masih memerlukan seleksi lebih lanjut pada populasi P1.
\end{abstract}

Kata kunci: Seleksi massa, produktivitas, jagung

\section{PENDAHULUAN}

Tanaman jagung (Zea mays L.) merupakan salah satu komoditas strategis yang dijadwalkan oleh pemerintah untuk bisa berswasembada pangan. Saat ini jagung telah menjadi komoditas perdagangan dunia, semua negara berlomba-lomba meningkatkan produksinya guna memenuhi permintaan industrinya.Pemilihan bibit dan varietas menjadi faktor penting terhadap pertumbuhan dan perkembangan tanaman jagung. Benih unggul diperoleh dari tanaman indukan yang memang telah teruji tahan penyakit dan berkualitas baik.

Produktivitas pertanian jagung lokal di Kabupaten Sumenep tergolong masih sangat rendah dan tidak stabil. Peningkatan produktivitas tanaman jagung lokal belum dapat dilakukan secara optimal mengingat berbagai kendala biofisik dan sosial ekonomi.
Salah satu penyebabnya petani menanam tanaman jagung lokal hanya sekedar mengisi lahan kosong. Faktor internal petani juga merupakan kendala yang tidak kecil pengaruhnya seperti keterbatasan kemampuan dan pengalaman petani membuat petani cenderung kurang memiliki dan memilih teknologi yang sama sekali baru, tetapi lebih menyukai teknologi yang telah ada. Salah satu upaya untuk meningkatkan produktivitas jagung adalah mengembangkan varietas unggul yang berdaya hasil tinggi dan adaptif pada kondisi lingkungan tertentu dengan disertai teknologi.

Jagung lokal varietas guluk-guluk diperoleh dari jagung yang ditanam oleh petani masyarakat Desa Guluk-guluk Kabupaten Sumenep. Jagung lokal ini disukai petani menanam jagung lokal dikarenakan harga benih yang lebih murah dibanding jagung hibrida. Selain itu juga jagung lokal yang ditanam petani sangat diminati oleh 
masyarakat lokal Kabupaten Sumenep yang memiliki umur genjah dan toleran lahan marginal serta tahan OPT. Jagung lokal ini banyak disukai petani Sumenep, terutama terkait pergiliran tanaman yang cukup ketat, kesuburan tanah rendah dan ketersediaan air yang hanya berasal dari curah hujan.. Berdasarkan kenyataan tersebut perlu upaya meningkatkan hasil produktivitas jagung lokal yang lebih tinggi untuk memenuhi kebutuhan pasar dan pendapatan petani sebagai tujuan akhir dari suatu usaha budidaya tanaman.

Produktivitas tanaman jagung lokal varietas guluk-guluk masih perluditingkatkan. Untuk meningkatkan produktivitas jagung lokal varietas gulukguluk, melalui program pemuliaan tanaman.Seleksi merupakan salah satu kegiatan utama dalam pemuliaan tanaman. Seleksi massa termasuk seleksi untuk memilih individu tertentu dengan maksud mendapatkan tanaman yang lebih baik dari campuran populasi dimana masing-masing anggotanya secara individual mempunyai perbedaan sifat atau karakter.Penerapan seleksi massa dilakukan dalam upaya memurnikan jagung varietas lokal gulukguluk. Kegiatan pemurnian genetik dilakukan untuk mengoptimalkan hasil produksi agar tidak terjadi pencampuran varietas yang mempengaruhi hasil produksi tanaman.Perakitan suatu varietas dapat dilakukan dengan cara memanfaatkan varietas lokal daerah tersebut melalui seleksi.Pembentukan jagung varietas lokal dapat diperoleh dengan jalan menggabungkan gen-gen dari berbagai sumber atau tetua. Untuk mendapatkan gen unggul perlu dilakukan pemurnian varietasnya. Pemurnian varietas ini diawali dengan pembentukan populasi dasar untuk membuat famili terpilih. Famili terpilih yang terbentuk diseleksi kembali dengan teknik seleksi berulang (rekombinasi), dengan cara ini akan diperoleh populasi yang lebih baik dari populasi awal.

\section{Rumusan Masalah}

Jagung lokal varietas guluk-guluk sudah lama ditanam oleh petani, benih diambil dari hasil panen sebelumnya tanpa melalui suatu proses seleksi yang baik, oleh karena itu perlu dilakukan penelitian dengan menerapkan metode seleksi massa dalam upaya untuk meningkatkan produktivitas tanaman jagung lokal genotipe tongkol tiga.Penelitian ini di lakukan menggunakan benih yang berasal dari hasil panenan musim tanam sebelumnya. Sesuai dengan metode seleksi massa (Dahlan, 1992) benih yang telah diseleksi oleh petani tersebut dijadikan sebagai populasi awal P0 selanjutnya diamati komponen produksinya untuk memilih tongkol-tongkol yang mempunyai berat biji yang tinggi untuk dijadikan sebagai benih dan selanjutnya dihitung respon seleksinya.

\section{Tujuan Penelitian}

Untuk meningkatkan produktivitas jagung lokal varietas guluk-gulukdapat dengan melakukan seleksi massa.

\section{METODE PENELITIAN}

\section{Tempat dan Waktu Penelitian}

Penelitian dilaksanakan di kebun percobaan Fakultas Pertanian Universitas Wiraraja. Benih yang ditanam diperoleh dari hasil panenan musim tanam Desember 2019, Penelitian ini dilaksanakan dalam bentuk evaluasi populasi awal P0 dan populasi P1 tanaman Jagung lokal varietas Guluk-guluk. Pemilihan populasi awal P0 sesuai dengan kriteria petani seperti tongkol kelihatan berukuran besar dan berat menurut perasaan petani sebanyak 20 tongkol. Penelitian ini dilakukan selama 4 bulan, yaitu pada bulan April hingga Juli 2020. 


\section{Tahapan Penelitian}

1. Tahap Penanaman

2. Tahap Pemeliharaan

3. Tahap Pengumpulan Data, sesuai dengan variabel pengamatan yang telah ditetapkan sehingga terdapat sebanyak 100 tanaman (tongkol) yang diamati. Dengan variabel pengamatan :

a. Jumlah biji dalam satu baris per tongkol : dihitung biji yang terdapat dalam satu baris pertongkol.

b. Jumlah biji per tongkol : dihitung semua biji yang terdapat dalam satu tongkol.

c. Panjang tongkol $(\mathrm{cm})$ : diukur mulai dari pangkal sampai di ujung tongkol menggunakan meteran.

d. Berat biji per tongkol (g) : ditimbang semua biji yang terdapat dalam satu tongkol menggunakan timbangan analitik.

e. Berat tongkol (g) : buah jagung yang sudah dikupas dari klobot kemudian dijemur dibawah terik matahari setelah itu ditimbang menggunakan timbangan analitik secara satu per satu.

\section{Teknik Analisis Data}

Data hasil pengamatan dianalisis dengan menggunakan analisis uji t-test pada taraf 5\% untuk mengetahui kemajuan seleksi. Perhitungan keragaman menggunakan rumus :

Dimana :

$$
\sigma^{2} p=\frac{\sum x^{2}-\left(\sum x\right)^{2} / n}{n-1}
$$

$\sigma^{2} \mathrm{p} \quad$ : ragam fenotip,

$\mathrm{x} \quad$ : nilai tiap karakter kuantitatif yang diamati dan

n : banyaknya data.

Simpangan baku $(\sigma)$ dihitung dengan menggunakan rumus:

$$
\sqrt{\sigma^{2} \mathrm{p}}=\sigma
$$

Ragam lingkungan $\left(\sigma^{2} e\right)$ diduga dari ragam tetua, dengan rumus:

$$
\sigma^{2} \mathrm{~g}=\frac{\sigma^{2} \mathrm{P} 1+\sigma^{2} \mathrm{P} 2}{2}
$$

Dimana :

$\sigma^{2} \mathrm{P} 1$ adalah ragam tetua 1 dan $\sigma^{2} \mathrm{P} 2$ adalah ragam tetua 2 .

Berdasarkan Syukur (2012), ragam genetik $\left(\sigma^{2}\right.$ g)dihitung dengan rumus :

$$
\sigma^{2} g=\sigma^{2} p-\sigma^{2} e
$$

Dimana :

$\sigma^{2}$ p adalah ragam fenotip dan

$\sigma^{2} \mathrm{e}$ adalah ragam lingkungan.

Heritabilitasartiluas $\left(\mathrm{H}^{2}\right)$, diperoleh dengan rumus:

$$
\mathrm{H}^{2}=\left(\sigma^{2} \mathrm{~g} / \sigma^{2} \mathrm{p}\right) \times 100 \%
$$

Mangoendidjojo (2003) menggolongkan nilai heritabilitas menjadi tiga, yaitu heritabilitas rendah $\left(\mathrm{h}^{2}<0,2\right)$, sedang $\left(0,2<\mathrm{h}^{2}<0,5\right)$ dan tinggi $\left(h^{2}>0,5\right)$.

\section{HASIL DAN PEMBAHASAN}

Penelitian ini menggunakan metode seleksi massa dalam meningkatkan produktivitas jagung lokal varietas gulukguluk memerlukan beberapa generasi ke generasi (siklus seleksi). Dalam setiap siklus seleksi yang diterapkan pada benih yang digunakan untuk generasi selanjutnya, harus dipilih dari tongkol-tongkol yang terbaik pada generasi sebelumnya. Usaha peningkatan produksi jagung lokal varietas guluk-guluk dapat ditempuh melalui beberapa cara. Salah satunya dengan meningkatkan setiap komponen-komponen produksi pada jagung lokal guluk-guluk dalam setiap siklus seleksi untuk memperoleh varietas jagung unggul.

Jagung lokal varietas guluk-guluk merupakan jagung lokal yang sudah beradaptasi baik dengan kondisi wilayah yang perbukitan dan rendah curah hujan. Penelitian ini merupakan kegiatan seleksi massa dari jagung lokal varietas guluk-guluk dengan memperbaiki potensi hasil dengan tanpa mengubah sifat-sifat dan karakter lainnya. 
Tabel 1. Nilai Rerata dan nilai varian dari P0

guluk dan P1 Jagung lokal varietas Guluk-

\begin{tabular}{lrrrr}
\hline \multicolumn{1}{c}{$\begin{array}{c}\text { Variabel } \\
\text { Pengamatan }\end{array}$} & \multicolumn{2}{c}{ P0 } & \multicolumn{2}{c}{ P1 } \\
\cline { 2 - 5 } & Rerata & Varian & Rerata & Varian \\
\hline $\begin{array}{l}\text { Jumlah biji per } \\
\text { baris }\end{array}$ & 23.667 & 12.933 & 26.490 & 11.121 \\
$\begin{array}{l}\text { Jumlah biji per } \\
\text { tongkol }\end{array}$ & 249.048 & 3665.548 & 295.800 & 2697.455 \\
$\begin{array}{l}\text { Panjang } \\
\text { tongkol }\end{array}$ & 11.286 & 1.489 & 12.754 & 3.175 \\
$\begin{array}{l}\text { Berat biji per } \\
\text { tongkol }\end{array}$ & 53.000 & 93.900 & 78.360 & 161.647 \\
Berat tongkol & 63.000 & 108.700 & 98.470 & 238.413 \\
\hline
\end{tabular}

Dari data tabel 1. seleksi massa yang didasarkan pada variabel pengamatan : Jumlah biji per baris dan Jumlah biji per tongkol menunjukkan varian yang rendah. Tetapi pada varibel pengamatan : Panjang tongkol, Berat biji per tongkol dan Berat Tongkol nilai variannya tinggi. Hal ini masih belum ada keseragaman yang disebabkan adanya varian yang tinggi. Data pada rerata menunjukkan peningkatan pada semua varibel pengamatan tetapi tidak diikuti keseragaman populasi karena disebabkan masih dalam satu siklus seleksi.

Berdasarkan tabel 1 menunjukkan nilai varian yang masih tinggi hal ini mengindikasikan kemajuan seleksi tinggi dan beragam karena semakin meningkatnya homogenitas populasi dari tanaman jagung lokal guluk-guluk. Sejalan dengan hasil penelitian Tabanao dan Bernardo (2015) menyatakan bahwa seleksi pada siklus awal cenderung memberikan kemajuan selekasi yang sangat besar karena keragaman populasi masih tinggi.

yang $\begin{array}{rr}\text { Tingginya nilai keragaman } \\ \text { dihasilkan,baik keragaman }\end{array}$
fenotipe maupun genetik, menunjukkan terdapat peluang besar untuk menyeleksi sifat-sifat yang diinginkan.Keragaman yang luas pada ragam genotipe dan fenotipe disebabkan oleh populasi yang digunakan adalah benih P1 yang tingkat segregasinya paling tinggi. Terjadinya perbedaan hasil dari setiap genotipe yang dicobakan disebabkan karena adanya perbedaan genetik. Perbedaan genetik ini mengakibatkan setiap varietas memiliki ciri dan sifat khusus yang berbeda satusama lain sehingga menunjukkan keragaman penampilan. Menurut Sitompul danGuritno (1995), perbedaan susunan genetik merupakan salah satu faktor penyebab keragaman penampilan tanaman. Program genetik yang akan diekspresikan padasuatu pertumbuhan yang berbeda dapat diekspresikan pada berbagai sifat tanaman yang mencakup bentuk dan fungsi tanaman yang menghasilkan keragaman pertumbuhan tanaman. Keragaman penampilan tanaman akibat perbedaan susunan genetik selalu mungkin terjadi sekalipun bahan tanaman yang digunakan berasal dari jenis yang sama.

Tabel 2. Nilai Rerata Perlakuan pengamatan untuk sifat-sifat yang diamati

\begin{tabular}{llc}
\hline \multicolumn{1}{c}{ Variabel } & \multicolumn{2}{c}{ Nilai Rerata Perlakuan } \\
\cline { 2 - 3 } Pengamatan & \multicolumn{1}{c}{ P0 } & \multicolumn{1}{c}{ P1 } \\
\hline Jumlah biji & 23.6667 & \\
per baris & $\mathrm{a}$ & $26.490 \mathrm{~b}$ \\
Jumlah biji & 249.0476 & \\
per tongkol & $\mathrm{a}$ & $295.800 \mathrm{~b}$ \\
Panjang & 11.2857 & \\
tongkol & $\mathrm{a}$ & $12.754 \mathrm{~b}$ \\
Berat biji & 53.0000 & \\
per tongkol & $\mathrm{a}$ & $78.360 \mathrm{~b}$ \\
Berat & 63.0000 & $98.470 \mathrm{~b}$ \\
\hline
\end{tabular}


tongkol a

Keterangan : Angka-angka yang diikuti oleh huruf yang sama pada kolom yang sama tidak berbeda nyata berdasarkan uji t $5 \%$

Tabel 2. Menunjukkan semua variabel pengamatan menunjukkan beda nyata berdasarkan uji t 0.05. Hasil uji t pada seleksi menunjukkan perbedaan nyata terhadap karakter jumlah biji per baris, jumlah biji per tongkol, panjang tongkol, berat biji per tongkol dan berat tongkol. Hal ini memperlihatkan pengujian terhadap populasi jagung setelah satu siklus seleksi menunjukkan nilai kemajuan seleksi yang meningkat. Berdasarkan nilai rata-rata perlakuan untuk semua karakter yang diamati mengalami peningkatan.

Seleksi massa dilakukan terhadap tanaman yang terpilih sehingga seleksinya merupakan persilangan acak diantara tanaman yang terpilih asaja. Seleksi tersebut dilakukan terhadap populasi P0 untuk mendapatkan populasi P1. Menurut Moll dan Stubber (1977), secara genetik perbaikan populasi tanaman jagung pada dasarnya adalah meningkatkan frekuensi allel yang diinginkan dengan jalan mengganti allel yang

\begin{tabular}{lcccc}
\hline $\begin{array}{l}\text { Variabel } \\
\text { Pengamatan }\end{array}$ & $\sigma^{2} \mathrm{p}$ & $\sigma^{2} \mathrm{~g}$ & $\sigma^{2} \mathrm{e}$ & $\mathrm{H}^{2}$ \\
\hline $\begin{array}{l}\text { Jumlah biji per } \\
\text { baris }\end{array}$ & 11.12 & 11.01 & 0.11 & 0.99 \\
$\begin{array}{l}\text { Jumlah biji per } \\
\text { tongkol }\end{array}$ & 2697.45 & 2670.48 & 26.97 & 0.99 \\
$\begin{array}{l}\text { Panjang tongkol } \\
\text { Berat biji per }\end{array}$ & 3.17 & 3.14 & 0.03 & 0.99 \\
tongkol & 161.65 & 160.03 & 1.62 & 0.99 \\
Berat tongkol & 238.41 & 236.03 & 2.38 & 0.99 \\
\hline
\end{tabular}

Keterangan $: \sigma^{2} p \quad=$ Ragam Fenotipe $\sigma^{2} \mathrm{~g}=$ Ragam Genotipe $\sigma^{2} \mathrm{e}=$ Ragam Lingkungan $\mathrm{H}^{2} \quad$ Heritabilitas dalam

arti luas

Heritabilitas merupakan perbandingan antara ragam genotipe dan ragam fenotipe dari suatu individu atau populasi suatu tidak dikehendaki dengan maksud meningkatkan nilai rata-rata populasi untuk karakter yang diinginkan.

Nilai kemajuan seleksi antara P0 dengan P1 menunjukkan nilai kemajuan seleksi yang berbeda nyata untuk semua sifat yang diamati. Kemajuan seleksi dapat diukur dari selisih antara nilai rata-rata populasi setelah seleksi (P1) dengan nilai rata-rata populasi sebelum seleksi (P0). Nilai kemajuan seleksi untuk setiap karakter produktivitas yang diamati menunjukkan bahwa karakterkarakter tersebut termasuk dalam efek maternal karena ekspresi karakter muncul dari genotipe tetua betinanya, bukan genotipenya sendiri. Efek maternal yang diteruskan hanya untuk satu generasi berikutnya. Karena dalam generasi berikutnya akan dibentuk berdasarkan genotipe induk betina yang baru. Hal ini sesuai dengan penelitian Sobir dan Syukur (2015) yang menyatakan bahwa pengaruh maternal ditentukan oleh gen yang berada di inti sel tetua betina.

Tabel 3. Nilai Ragam Fenotip, Ragam Genetik, Ragam Lingkungan dan Nilai Heribilitas pada Variabel yang Diamati tanaman (Mangoendidjojo, 2003). Tinggi rendahnya heritabilitas menunjukkan besarnya pengaruh genotipe dan lingkungan terhadap individu atau populasi tanaman tersebut. Mangoendidjojo (2003) menggolongkan nilai heritabilitas menjadi tiga, yaitu heritabilitas rendah $\left(h^{2}<0,2\right)$, sedang $\left(0,2<h^{2}<0,5\right)$ dan tinggi $\left(h^{2}>0,5\right)$. Nilai heritabilitas yang rendah 
atau mendekati nol berarti keragaman fenotipe hanya disebabkan oleh lingkungan, sedangkan nilai heritabilitas dengan nilai satu berarti fenotipe hanya disebabkan oleh faktor genotipe.

Menurut Hanson (1963), nilai heritabilitas dalam arti luas merupakan keragaman genetic total dalam kaitannya dalam keragaman fenotip. Sedangkan menurut Poespodarsono (1998) mengemukakan bahwa makin tinggi nilai heritablitas suatu sifat, makin besar pengaruh genetik dibanding lingkungan. Dalam penelitian ini, heritabilitas dalam arti luas untuk semua sifat yang diamati mempunyai nilai tinggi. Hal ini berarti bahwa peranan faktor genetik pada penampilan fenotip sangat besar, atau peranan lingkungan pada penampilan tersebut kecil. Tingginya nilai heritabiltas ini memberikan kriteria bahwa seleksi untuk kedua sifat tersebut dapat dilakukan pada generasi awal. Hal ini sesuai dengan pendapat Rahman (1991), Mardjono, $d k k$ (1991), dan Rohman, $d k k$ (1991), bahwanilaidugaheritabil itas yang tinggi memberikan informasi bahwa sifat tersebut ditentukan oleh faktor genetik tanaman yang bersangkutan. Dengan demikian dapat dikatakan bahwa sifat tersebut mempunyai nilai yang bersifat konstan, sehingga seleksi pada karakter ini dapat dimulai pada generasi awal. Niai duga heritabilitas yang rendah menunjukkan bahwa seleksi terhadap karakter ini lebih efktif pada generasilanjut.

Nilai heritabilitas yang tinggi pada sebagian besar variabel yang diamati menunjukkan, bahwa peran gen dalam mempengaruhi fenotipe lebih dominan dibandingkan dengan pengaruh lingkungan, yang berarti variabel yang diuji memiliki keragaman genotipe yang besar. Hal ini ditunjukkan oleh besarnya nilai ragam genotipe dari pada ragam lingkungan. Nilai heritabilitas yang tinggi sangat menentukan stabilitas hasil suatu tanaman, sedangkan nilai heritabilitas yang rendah atau mendekati nol menunjukkan bahwa hampir tidak dapat dilakukan seleksi pemuliaan tanaman pada populasi tersebut, sehingga dengan adanya nilai heritabilitas dari sebagian besar variabel yang diamati dapat digunakan sebagai acuan untuk program pemuliaan. Nilai heritabilitas yang tinggi menunjukkan, bahwa faktor genotipe lebih menentukan dari pada faktor lingkungan untuk penampilan (fenotipe) tanaman jagung tersebut atau memiliki stabilitas gen yang tinggi. Hal ini sesuai dengan pernyataan Knight et al. (1979), bahwa nilai heritabiltas yang tinggi berarti semakin besar pengaruh genotipe dan semakin kecil pengaruh lingkungan, sehingga dapat digunakan untuk kemajuan pemuliaan, walaupun galur-galur tersebut ditanam pada lingkungan yang berbeda hasil yang diperoleh akan tetap stabil.

Nilai duga heritabilitas diperlukan untuk melakukan seleksi, nilai duga heritabilitas yang tinggi akan menyebabkan seleksi menjadi lebih efektif karena pengaruh lingkungan sangat kecil sehingga faktor genetik lebih dominan dalam penampilan genotipe tanaman, sedangkan pada karakter yang memiliki nilai duga heritabilitas rendah seleksi akan berjalan kurang efektif karena penampilan fenotipe tanaman lebih dipengaruhi faktor lingkungan dibandingkan dengan faktor genetiknya. Dengan nilai duga heritabilitas yang tinggi, intensitas seleksi, dan tandar deviasi fenotip yang tinggi akan menyebabkan kemajuan genetik suatu karakter tanaman menjadi tinggi (Rostini, 2006).

Nilai heritabilitas yang tinggi untuk suatu karakter menggambarkan karakter tersebut penampilannya lebih ditentukan oleh faktor genetik. Karakter yang demikian mudah diwariskan pada generasi berikutnya, sehingga seleksinya dapat dilakukan pada generasi awal. Nilai heritabilitas rendah untuk suatu karakter menggambarkan karakter tersebut sangat dipengaruhi oleh faktor lingkungan, 
pewarisannya sulit sehingga seleksi hanya efektif dilakukan pada generasi lanjut (Fehr, 1987).

\section{KESIMPULAN}

Seleksi massa pada tanaman jagung varietas guluk-guluk antara populasi awal(P0)dengan populasi hasil seleksi(P1) menunjukkan kemajuan seleksi yang berbeda nyata berdasarkan uji t0,05 pada semua sifat yang diamati.

\section{DAFTAR PUSTAKA}

1. Fehr, R.W. 1987. Principles of Cultivar Development Vol I. Macmilan Inc. New York.

2. Knight, R.; G.M. Halloran; K.S. Mc. Whirter and D.H.B. Sparrow, 1979. Plant Breeding . Australian Vice-Chancellors Communittee, Australian.

3. Mangoendidjojo 2003. Dasar-Dasar Pemuliaan Tanaman. Penerbit Kanisius Yogyakarta

4. MollR.H.andStubberC.W.1971.Compariso nsof

ResponsetoAlternativeSelectionProcedure $\mathrm{s}$ Initiatedwith TwoPopulationsofMaize(Zea mays L.). Crop. Sci. 11:706-711

5. Poespodarsono S, 1988,Dasar-dasar Ilmu Pemuliaan Tanaman, PAU IPB Bogor, Bekerjasama dengan Lembaga Sumberdaya Informasi-IPB.

6. Rostini, N. 2006. Heritabilitas, Kemampuan Genetik dan Korelasi Karakter Daun dengan Buah Muda, Heritabilitas, Pada 21 Genotip Nenas. Zuriat 10 (2): 88-98. Juli-Desember 2006

7. Sitompul, S.M. dan B. Guritno. 1995. Analisis Pertumbuhan Tanaman. GMU Press. Yogyakarta.

8. Soetarso, 1991. Ilmu Pemuliaan Tanaman. Jur. Budidaya Pertanian Fak. Pertanian UGM, Yogyakarta.
9. Tabanao, D.A., and R Bernardo, 2005. Genetic VariationinMizeBreedingPopulation with differentnumbersofparents.CropSci.,45:23 01-2306 